\title{
An Analysis of Teacher Talk used by English Teacher at SMKN 5 Samarinda
}

\author{
Siti Aminah ${ }^{1)}$, Dedi Rahman Nur ${ }^{2)}$, Ariyanti ${ }^{3)}$ \\ ${ }^{1)}$ Program Studi Pendidikan Bahasa Inggris, Fakultas Keguruan dan Ilmu Pendidikan, \\ Universitas Widya Gama Mahakam Samarinda, Indonesia \\ Jl. KH. Wahid Hasyim No. 28 RT.007 Kota Samarinda, Provinsi Kalimantan Timur \\ ${ }^{2}$ Program Studi Pendidikan Bahasa Inggris, Fakultas Keguruan dan Ilmu Pendidikan, \\ Universitas Widya Gama Mahakam Samarinda, Indonesia \\ Jl. KH. Wahid Hasyim No. 28 RT.007 Kota Samarinda, Provinsi Kalimantan Timur \\ 3) Program Studi Pendidikan Bahasa Inggris, Fakultas Keguruan dan Ilmu Pendidikan, \\ Universitas Widya Gama Mahakam Samarinda, Indonesia \\ Jl. KH. Wahid Hasyim No. 28 RT.007 Kota Samarinda, Provinsi Kalimantan Timur \\ *Email Penulis Korespondensi: sitiaminah071095@gmail.com, d.blues84@gmail.com, \\ ariyanti.muflihin@gmail.com,
}

\begin{abstract}
This research used qualitative research method. The research design of this study is descriptive study. The researcher used interview as the instruments. The participants in this study were teachers of SMK Negeri 5 Samarinda and the researcher took three teachers. The research used purpose sampling technique. In this research the data collection techniques is using interviews to find out the types of teacher talk and the reasons for the teacher used teacher talk. The findings showed that there are three teachers talk used by teacher such as asking question, lecturing and giving direction. Nevertheless, there are three main reasons for the teacher used the teacher talk such as students' language ability, students' motivation and students' participation.
\end{abstract}

Keywords : Teacher Talk, Direct Teacher Talk, Indirect Teacher Talk 


\section{INTRODUCTION}

Teacher talk can build good interaction between teacher and student because the teacher transfers the lesson to students from talking. Teacher talk focus on the talking time of teacher in the lesson. Along with the teacher talk in the classroom, teacher could recognize how was the students' understanding toward the lesson. In addition, teacher talk can prevent students from being busy with their activities such as talking with friends when teacher is explaining. In this case, when teachers use teacher talk means indirectly teachers involve students in teaching and learning process. Based on Inecay (2010) and Yanfen \& Yuqin (2010) teacher talk affects the result of the teaching and learning process. It means that the teacher talk is important in teaching English. Teaching is the activity of organizing student activities and providing good learning so that the students can learn well. Further, Amatari (2015) explains that the relation between students and teacher is a crucial factor in the teaching process and must be considered an important aspect of methodology. Instructing and learning process is a case of collaboration, it includes connection among instructor and understudies in which they impact one another in (Dagarin 2004).

As Yanfen \& Yuqin (2010) points out that teacher talk is the language in the classroom that takes up a major portion of class time employed to give direction, explain activities and check student understanding. It is vital to know the sorts of instructor talk classifications occuring in the classroom. Kinds of instructor talk happen in the classroom are essentially arranged by Flanders. Teacher talk has two sub categories, indirect influence and direct influence. Roundabout impact is at that point broken down into: tolerating sentiments, acclaims or support, tolerating students' thoughts, and inquiring questions. Coordinate impact is isolated into addresses, giving bearings, and criticizing or legitimizing specialist.

1. Direct Teacher Talk

In the direct teacher talk occur in the classroom and. Adegoke (2003) states that direct teacher talk is at play in the classroom when the teacher adopts lecture method, states the teacher's opinion or ideas, justifies teacher's authority or use the authority, direct student's action and criticizes student's behavior. There are three categories in direct teacher talk:

\subsection{Lecture}

Lecture is the form of verbal interaction that is used to give information, opinions, facts or ideas to the students. Lecture is characterized as a strategy of educating by which the educators gives an verbal introduction of actualities or standards to learners and the lesson ordinarily being mindful for note taking, more often than not infers, small or no lesson cooperation by such implies as addressing or dialog amid the course period in (Kaur, 2011). The presentation of material may be used to introduce, review, or focus the attention of the class.

\subsection{Giving Directions}

The decision about whether or not to classify the statement as a directions or commands must be based on the degree of freedom that the student has in response to teacher direction. Brown (2001) explains that students need some direction and facilitation of information on how they should demonstrate the whole ideas they own systematically. In accordance, [6] suggest that giving direction will provide students with opportunity for practicing their capability in English language. A good direction will lead the teaching and learning process into a successful one. 


\subsection{Criticizing or Justifying Authority}

Statements intended to change students' behavior from non - acceptable to acceptable pattern; bawling someone out; stating why the teacher is doing what he is doing; extreme self - reference. If the teacher is explaining himself or his authority, defending himself against the student or justifying himself the statement falls in this category. In the meantime, teacher should be able to comminicate anger, dissatisfaction and annoyance with students [6]. Additionally, most of criticizes that take place are intended to keep the students pay attention and listen to the speaker at the present time [6].

\subsection{Indirect Teacher Talk}

Indirect teacher talk occur in the classroom and out of classroom. Adegoke (2003) explain that indirect teacher talk is at play in the classroom when the teacher gives maximum opportunity to the students to participate in the teaching learning activities in the classroom interaction. Indirect influence consist of four categories: accepting feelings, praises or encouragement, accepting ideas, and asking questions.

\subsection{Accepting Feelings}

This kind of statement often communicate to students both acceptance and clarification of the feeling. Also included in this category are statements that recall past feeling, refer to enjoyable or uncomfortable feelings that are present, or predict happy or sad that will occur in the future. Putri (2015) affirms that teacher should provide a safe environment for learning and it includes accepting students' feelings. Accordingly, students should not be punished for exhibiting their feelings.

\subsection{Praise or Encouragement}

Included in this category are jokes that release tension, but not those threaten students or are made at the expanse of individual students. Often praise is a single word: great, fine, good, etc. Encouragement is slightly different and includes statements such as "continue", "go on", "go ahead", etc. Studies have found that teachers do not praise deliberately but rather it is a spontaneous reaction to students' behavior and to their subtle demands for praise Crespo (2000). On the other hand, Crespo also asserts that learning is intrinsically rewarding and learners should not be bribed or forced to learn. Davies (2011), on his inquire about includes that lauding may cause a alter of pace in a lesson, which may result in a misfortune of concentration. According to Aisyah (2016), appraisals are not merely indicated by saying "good job!" or "well done !" but it can be shown in a form of saying "uh - huh!" or simply by teacher's repetition of students' answer.

\section{Accepting Ideas}

Accepting or using ideas of students bring out students' willingness to give their ideas. This category is quite similar with accepting feelings, however it includes only acceptance of students' ideas and not acceptance of expressed emotion. When a students' makes a recommendation, the educator may summarize the student's articulation, or summarize what the understudy has said. This category could be observed through teacher's confirmation such as "well, that's interesting point of view" or "I understand what you mean". Also through the repetition of students' statement by using his/her own word and build or develop the ideas given by students by having a class discussion as worthy of consideration in (Aisyah, 2016).

3.1 Asking Questions

Brown (2001) said questioning in interaction as a way to stimulate students speak up their thoughts. This category includes only questions to which the teacher expects an answer from the students. Teacher usually start with displaying the questions which the answer is common knowledge. There is a true or false answer of the questions. According to Ambrosio (2013), 
found that many studies affirmed that critical thinking using teacher questions facilities students to answer the questions that will help them in understanding the issues they are experiencing in society. Nevertheless, there is time when the teacher asks questions, but they keep up their lecture without receiving any answers.

The problem is when the teacher explained the materials to the students, there was only several students that follow the direction and when the teacher talked to the students, they are busy with their activities like talking with their friends. In line with the background above, this study focuses on what types of teacher talk that used by English teacher in SMK 5 Samarinda. From the explanation above the researcher conducts a study entitled "An Analysis of Teacher Talk used by English Teacher at SMKN 5 Samarinda".

\section{METHODOLOGY}

The design of this research is descriptive qualitative in order to describe the findings. Descriptive qualitative research is the way that provide a description of a particular situation or events. Based on Polit and Hungler (2004) said that descriptive research refers to study that have as their main objective the accurate portrayal of the characteristics of person. According to Gay, Mills, \& Airasian (2012), population is the group to which a researcher would like the results of a study to be generalizes. From the explanation of population above, the population of this research was all of the English teacher at SMKN 5 Samarinda it is located in Jl. KH. Wahid Hasyim 1 Samarinda city. In this study, the subject is determined purposively. The reasons are the teacher is available and willing to be observed and become the subject of this research. The source of the data in this research is the teacher who teaches English at SMKN 5 Samarinda.

The researcher use structured interview. In this research, before conducting interview the researcher has made several questions to ask. The structure of the interview is the interviewer will ask questions according to the interview guide that has been made without any additional questions. For the instrument of collecting data the researcher makes an interview guide. Interview guide is list of question that is formulated by researcher used to get information needed for the research through interview between interviewer and interviewee.

To gather the data of this research is prepare the tool that used interview guide. Then, the researcher asks the permission to the school to do research in that school. After that, ask the permission to the teacher. The last, the researcher did interview to the teacher who teach English subject. After collecting the data, the researcher analyzes the data from interview. Data analysis is a procedure where the researcher systematically looks for and arrange the data in order to raise understanding. In other word (Pratama, 2015) said that data analysis is the final activities in a research are analyzing and interpreting the data collected and presenting the result. The researcher analyzes the data according to the instrument given. The researcher analyze it by using steps of qualitative data analysis adapted from (Miles, Huberman, \& Seldana, 2014). There are three steps to analyze the qualitative data, namely: 1. Data Condensation. 2. Data Display, 3. Conclusion Drawing or verification.

\section{FINDINGS AND DISCUSSION}

Based on the results above it can be concluded that there are three types of teacher talk that they used when teaching in the classroom such as giving direction, lecturing and asking question. As the result of interview found that all of teacher used giving direction in the classroom. It is supported by [2] found that giving direction is more used by teachers in the class because giving direction is the way to make the class more active. Then in his findings 
said that giving direction was found more used by teacher in the class. From the results of the interview it was found that the teacher used giving direction depending on the theme or topic of learning and make student easier to understand the lesson. Besides that, two of the three teachers used lecturing when they were teaching in the classroom. According to the findings of Yanfen \& Yuqin (2010) that lecturing was used by the teacher when students provide the expected answer, they still prefer to be commented, rather than being just simply acknowledged. As Yanfen \& Yuqin (2010) said in his findings that lecturing is a direct way to help students by means giving definition, an example, an explanation or by signaling the problem. Furthermore, one of the three teachers used to ask question. This finding was apparently with the findings of Yanfen \& Yuqin (2010) found that inquiring questions was the commonest way utilized by the educator to know understudy understanding and make them conversation more within the classroom.

After knowing the types that are used by teachers, the researcher also wants to know the reasons why teachers used teacher talk. It was found that there are three reasons for the teacher used teacher talk. All of the reasons will be explained below.

a. Students' language ability

The fist reason is because stdents's language ability. The challange derived from the classroom sitation in which not all the students are able understand and speak in English. As teacher A stated that some of students were not talk or not active in the classroom because they don't undestand so that way teacher should stimulate them by used teacher talk so by used teacher talk it will stimulate them to try to speak english. From the finding above the reason teacher used teacher talk is because of students' language ability. This is supported by Aisyah (2016) said that students language ability is one of the reasons which influenced of teacher talk occured in the classroom. It is because of the process of stimulated students to talk is by using teacher talk.

b. Students' motivation

Beside that, the reason teacher used teacher talk is because to motivated students in order to stimulated the student to speak in english. As teacher B claimed in the interiew that to motivate students who cannot speak English because students who is motivated to speak they will speak. Based on the finding, the reason teacher used teacher talk is students' motivation because if students are motivated to speak English, then they will speak English. This is supported by Aisyah (2016) who assert that students's motivation also plays a part in the occurrence of teacher talk in the classroom.

c. Students' participation

The last reason is because students' participation, according to teacher stated that there are active students and less active students. As she claimed in the interview not all students are active in speaking English, to make students who are less active in speaking English teachers use teacher talk in their teaching. If the students are remarkably being active, the teacher can decrease their talk. On other side, if students are really shy to speak therefore teacher have to stimulate them. In conclusion, the reason teacher used teacher talk is students' participation supported by Aisyah (2016), she said that students' participation in the classroom become one of the consideration for the teacher in choosing teacher talk. This happened based on the fact that each students is different.

\section{CONCLUSION}

Regarding to types of teacher talk used, teachers used three types of teacher talk among others asking question, giving direction and lecturing in the classroom. Regarding to reasons for teacher used teacher talk, from the findings it can be conclude that there are three main 
reasons for the teacher used the teacher talk. The first reason is students' language ability it causes not all the students are able understand and speak in English, to stimulate students to talk is by using teacher talk. The other reason is students' motivation because teachers want to motivated students in order to stimulate the student to speak in English. The last reason is students' participation in order to make student active to speak English. Based on the findings here the researcher would like to offer the following suggestions: For the Teacher in Senior High School level, the teacher should increase their teacher talk it is amount of direct teacher talk or indirect teacher talk, which is it is includes accepting feelings, criticizing or justifying, praise and encouragement. This is important because such talk has strong motivational impact on the learners. They need to be encouraged, paid attention to, and tolerated, but also criticized and reminded. In that way, their learning will be more effective. Learners' exposure to the target language should be primarily attempted by using more English expressions in the teacher's talk. In that way, not only are the learners accustomed to hearing spoken English, but they are also given a lot of opportunity to respond to the teacher in English. Besides that as a good facilitator, the teacher also has to be a good model for the students, he / she should learn more and always enriches his / her knowledge. The teacher can do that by letting them ask questions or express their own ideas. For the Learners, they should make themselves get more used to English. They can do it by using English in their daily life. I know it is difficult to do since their environment is not English-speaking environment. But in fact, they do not want to use it because they are afraid to make mistakes. They should know that they can learn from the mistakes they make, and the worst thing is that most Indonesian learners think if they speak English all the time, their friends, who cannot speak English think that they are big headed. They should ignore that from their mind because it is absolutely wrong. The ones, who cannot speak English, should learn from their friends who can speak English well. It will make them able to speak in English. If the learners use English every time, they will get used to using it. 


\section{BIBLIOGRAPHY}

[1] G. Inecay, "The role of teacher talk in young learners' language process," Procedia Soc. Behav. Sci., pp. 277-281, 2010.

[2] L. Yanfen and Z. Yuqin, "A Study of Teacher Talk in Interactions in English Classes," Chinese J. Appl. Linguist., vol. 33, no. 2, 2010.

[3] V. Odiri Amatari, The Instructional Process: A Review of Flanders' Interaction Analysis in a Classroom Setting, vol. 3. 2015.

[4] M. Dagarin, "Classroom Interaction and Communication Strategies in Learning English as a Foreign Language,” 2004.

[5] G. Kaur, "Study and Analysis of Lecture Model of Teaching," Int. J. Educ. Plan. Adm., vol. 1, no. 1, pp. 9-13, 2011.

[6] R. R. Sofyan and M. Mahmud, "Teacher Talk in Classroom Interaction: A Study at an English Department in Indonesia,” 2014.

[7] D. S. Putri, “THE ANALYSIS OF TEACHER TALK AND THE CHARACTERISTIC OF CLASSROOM INTERACTION IN ENGLISH AS A FOREIGN LANGUAGE CLASSROOM,” J. English Educ., vol. 3, no. 2, 2015.

[8] S. Crespo, "Praising and correcting: prospective teachers investigate their teacherly talk," Teach. Teach. Educ., pp. 739-758, 2000.

[9] M. J. Davies, “Increasing students' L2 usage: An analysis of teacher talk time and student talk time," pp. 1-22, 2011.

[10] N. Aisyah, “AN ANALYSIS OF TEACHERS' TALK IN AN EFL CLASSROOM,” J. English Educ., vol. 4, no. 2, 2016.

[11] Y. M. U. Ambrosio, "Questions in Teacher Talk: What Questions are Frequent and how it Affects Critical Thinking," pp. 70-75, 2013.

[12] L. R. Gay, G. E. Mills, and P. Airasian, EDUCATIONAL RESEARCH Competencies for Analysis and Applications. 2012.

[13] D. W. PRATAMA, “TEACHER AND LEARNERS' TALK IN THE CLASSROOM INTERACTION AT TENTH GRADE STUDENTS OF SMA JAWAHIRUL HIKMAH TULUNGAGUNG IN ACADEMIC YEAR 2014/2015,” 2015.

[14] M. B. Miles, A. M. Huberman, and J. Seldana, Qualitative Data Analysis A Methods Sourcebook, Third Edit. 2014. 